\title{
IX. Method of whitening the gray marine salt to fit it for domestic purposes instantaneously, and without the aid of heat
}

\section{Pajot Descharmes}

To cite this article: Pajot Descharmes (1802) IX. Method of whitening the gray marine salt to fit it for domestic purposes instantaneously, and without the aid of heat, Philosophical Magazine Series 1, 13:49, 40-41, DOI: 10.1080/14786440208676088

To link to this article: http://dx.doi.org/10.1080/14786440208676088

曲 Published online: 18 May 2009.

Submit your article to this journal $\pi$

Џll Article views: 2

Q View related articles $\longleftarrow$ 
elfe than the exterior fide of the firft row of cells, as the illuftrious Malphigi fuppofed. The pith in all plants is compofed of hexagonal cells. In herbaceous plants, and particularly thofe which are highly fucculent, thefe cells are often filled with juices more or lefs thick or coloured. In ligneous plants, naturally drier, they are, on the other hand, almoft entirely empty, and tranfparent. The cellular tiffue in bulbous roots is pulpy and fucculent; in the cotyledons it is hard and brittle; and in the albumen and feeds it is dry and arid. The parenchyme of the leaves, of the bracter, ftipulæ, and calyces, is formed by cells filled with a juice almoft always coloured, and green. The rich corollæ, which difplay to the light the elegance of their forms and the fplendour of their colours, but of which the beauty and frefhnefs vanifh in a noment, are not fo thin as the delicate membranes of the cellular tiffue: the juices which fwell the tranfparent utriculi of which they are formed give them thefe colours; the one fometimes diffufed into the other by imperceptible tints, fometimes abruptly oppofed, and heightening their fplendour by the contraft. Here the cellular tiffue is fo delicate, that the flighteft touch is fufficient to alter and tarnifh it: the leaft preffure reduces it to mucilage, and it appears to be the momentaneous product of the air and water. This tiffue is obferved alfo in the ftamina and the piftils. The pollen, that fine duft which cortains the fubtile fluid neceffary for fecundation, appears to be only an accumulation of fmall bags formed of the cellular tiffue: in a word, it is this tiffue which, by dilating itfelf, produces fucculent fruits.

The cells are proportionally more abundant in herbs than in trees, and in young thoots than in old timber. The embryo is compofed almoft entirely of cellular tiffue. The medullary radii, which extend from the centre to the circumference in the trunks and branches of trees with two cotyledons, are fometimes alfo nothing but a thin membrane of cells.

[To be courinued.]

IX. Metbod of wbitening the Gray Marine Salt to fit it for domeftic Purpojis inftantaneoufly, and without the Alit of Heat. By PaJot Descharmes*.

I

TRAY or unrefined marine falt, as every body knows, is covered with a tihn earthy cruft which alters more or lefs its whitenefs; and it is a matter of fome confequence, both in

* From tile fame.

regard 
regard to cleanlinefs and health, to purify it from this heterogencous fubftance which covers all the faces of its cryftals. Hitherto this falt has been purified or refined only by folution, filtration, or precipitation, according as the operation is performed on a large or a fmall fcale, and then by evaporation. This method requires time, wood or charcoal, and proper veffels. Many perfons, however, are unacquainted with this procefs; fometimes they have not leifure to employ it; and fometimes they have neither the neceffary veffels nor fuel.

I have thought, therefore, that a procefs which requires neither fire nor particular veffels, is attended with no expenfe, may be practifed at all times, and is within the reach of every one, might be of general utility. This method is as follows:

Take four ounces of gray falt, and, if dry, befprinkle it gently with water till it be only what is called moift; but it will be very feldom neceffary to have recourfe to this operation. Put the falt into the corner of a table napkin or piece of linen cloth, and form the cloth into a kind of knot or bag, which you muft hold in one hand, while with the other you rub and thake the falt againt the infide of the cloth for the fpace of half an hour. Then hift the falt to another place of the cloth, fucceffively repeating the fame manœurre fix, feven, or eight times, according as the falt is more or lefs grays After the falt has been rolled for the firft time, the cloth begins to exhibit fpots occafioned by the earth which the falt depofits, and of which the intenfity fenfibly decreafes at each change of place till they entirely difappear. In general, the falt mult be befprinkled every two or three times that its place is changed. The bleaching will be accelerated by pounding the falt lightly before it is befprinkled.

After two or three afperfions and rubbings, the falt is, in general, as pure and white as that refined, according to the ufual method, by folution and evaporation. The lofs in both cafes is nearly the fame; that is to fay, about an eighth, when the falt is dry, and when care has been taken at each change of place to thake off the grains which adhere to the cloth. It is, for the moft part, the whiteft falt that adheres in this manner; and it may be thaken off without fear, as the earth depofited on the cloth cannot detach itfelf till the cloth is dry. The gray falt of commerce contains in general 12 per cent. of foreign matters, nearly one-half of which is water, and about as nuch earth.

This procefs, which on account of its fimplicity I confider as likely to become ufeful for domeltic purpofes, might perhaps be applicable to falt manufactories and falt refineries. 